\title{
Sentidos identitários paradoxais de TV na Internet
}

\section{Paradoxical senses of TV} identity on Internet

Suzana Kilpp ${ }^{1}$

\footnotetext{
${ }^{1}$ É professora do Programa de Pós-graduação em Ciências da Comunicação e do curso de Comunicação Digital da Universidade do Vale do Rio dos Sinos, e pesquisadora do Conselho Nacional de Desenvolvimento Científico e Tecnológico (CNPq). Pesquisa financiada com recursos do CNPq e Fundação de Amparo à Pesquisa do Estado do Rio Grande do Sul (Fapergs). Coordena o grupo de pesquisa Audiovisualidades da Tecnocultura: Comunicação, Memória e Design (TCAv).E-mail: sukilp@unisinos.br
} 
Resumo: o artigo objetiva propor o conceito de estado-vídeo como alternativa a paradigmas que associam os conteúdos televisivos a que se assiste na Internet a uma espécie de televisão expandida, digitalizada ou remediada na rede universal de computadores. Toma por referência resultados parciais do monitoramento de dois sítios genealógicos: um de emissora de TV off-line sitiada na Internet, e outro de emissora que não tem existência off-line, que é nativa da Internet. A análise empírica é feita sob a metodologia das molduras, e o referencial teórico recorre a vários autores que são articulados para produzir a crítica e encaminhar as considerações finais.

Palavras-chave: televisão; molduras; estado-vídeo.

Abstract: this article aims to propose the video-state concept as an alternative to the paradigms in which the television contents situated on the Internet have been associated with a kind of expanded, digitized or remedied TV in the universal network of computers. This article analyzes partial results of the monitoring of two genealogical sites: an offline TV network on the Internet, and another network that has no existence offline, which comes from the Internet. The empirical analysis is made using the methodology of the frames, and the theoretical references are based on various authors to produce criticism and forward the final considerations.

Keywords: television; frames; video state. 


\section{Introdução}

As mídias veiculam, entre outras coisas, imagens do mundo vivido aparentemente como se fossem imagens vistas através de janelas ou em espelhos. Inexoravelmente elas o fazem nos termos que são próprios a cada uma delas, isto é, nos termos do aparelho (hardware) e do programa (software), no sentido de Flusser (2007). Isso significa dizer que elas criam cenas do mundo de acordo com a técnica que lhes é própria, e que as imagens do mundo vivido que veiculam não o espelham: elas são conceitos do mundo, isto é, elas são partes de um mundo codificado (FLUSSER, 2007) sob o viés (ou código) de cada mídia. Conforme sua técnica específica (que inclui uma lógica operacional), as mídias atribuem sentidos identitários aos seus construtos por meio de um conjunto de molduras e moldurações por elas praticadas, sendo que os emolduramentos ${ }^{2}$ finais do espectador dependem ainda de seu repertório pessoal e cultural, estando circunscritos a um imaginário compartilhado do que sejam tais construtos.

Mais adiante se retomará a incidência da noção de programa e de programação nos termos de Flusser sobre a questão de que trata o artigo. Mas, para não confundir o leitor, no texto que segue imediatamente, o verbete "programa" passa a designar exclusivamente o construto televisivo que rotula certos conteúdos veiculados como sendo tal ou qual: uma unidade autônoma de conteúdos audiovisuais afins que se desenrolam em blocos sucessivos dessas unidades para a assistência. No momento da assistência, os blocos de um determinado programa são justapostos aos blocos de outros programas e intercalados por blocos de outras unidades autônomas (como os comerciais, as vinhetas e os promos, por exemplo), sujeitando-se, portanto, à lógica da "programação", verbete que passa, assim, a designar o conjunto dos programas de uma emissora.

Ressalve-se, porém, que o mesmo verbete é usado pelas emissoras para denominar três coisas diferentes:

a) a grade de programação bruta ou virtual (a que organiza fora do ar uma sucessão de tipos ou gêneros de programas que devem ir ao ar em tal ou qual horário, de acordo com a presumida assistência no horário em questão e em relação à qual os anunciantes dos programas têm maior ou menor interesse);

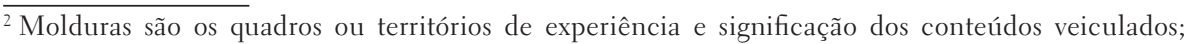
moldurações são as montagens técnicas e estéticas no interior das molduras; emolduramentos são os sentidos finalmente agenciados entre emissores e receptores, igualmente circunscritos a um imaginário social minimamente compartilhado entre as partes (KILPP, 2003).
} 
b) a grade de programação anunciada ao espectador (aquela que, de tempos em tempos, atualiza os conteúdos virtuais de cada programa: por exemplo, qual a "novela das nove", qual o filme da Sessão da Tarde etc.);

c) e a programação efetivamente assistida pelo espectador (a que é montada no ar, em fluxo contínuo, e que, além dos programas, inclui as demais unidades autônomas já referidas).

É assim quando a TV aberta veicula "filmes" como o conteúdo anunciado de um de seus vários programas. Sessão da Tarde, por exemplo, é um programa de TV cujo teor é, a cada vez que vai ao ar, de um filme direcionado à audiência da tarde (ao público presumido desse horário, no qual certos anunciantes têm interesse comercial) $)^{3}$, devidamente ajustado às janelas ${ }^{4}$ da programação em fluxo da emissora. Porque essas janelas têm uma duração em tempos cronometrados (em grande parte por conta das inserções comerciais contratadas para aquele horário e, também em grande parte, por conta do perfil da audiência imaginada), o filme é cortado, dublado e formatado aos moldes da lógica televisiva.

Também é assim quando, na TV por assinatura, organizam-se conteúdos por "canais" - que não correspondem necessariamente aos canais da TV aberta e incluem muitos outros, para além dos autorizados à transmissão aberta -, e se segmentam os "programas" - que incluem muitos que não são veiculados na TV aberta, de acordo com a legislação da TV por assinatura, que a preconiza como espaço de veiculação de produtos/produtores principalmente não vinculados às emissoras autorizadas a transmitir em canal aberto. Ou seja, também nesse caso muitos filmes são cortados, dublados (ou não) e formatados aos moldes da lógica da empresa (Net, Sky ou outra) que distribui a programação de TV segmentada.

Quando os conteúdos televisivos passam a ser veiculados na Internet em sítios das emissoras de TV off-line, há ainda outros atravessamentos nos sentidos identitários dos programas e da programação, os quais são pautados pelas lógicas da Internet, que são muito diferentes das lógicas de qualquer veiculação off-line 5 .

\footnotetext{
${ }_{3}^{3}$ Sub-repticiamente e em tese, os filmes são avaliados pelas emissoras como mais ou menos adequados a tal propósito, pelo tema, pelo gênero ou sabe-se lá por qual outro critério. Mas, de fato, a cada vez que se tenta deduzir o critério da emissora para tal classificação, é-se confrontado com critérios dúbios, casuísticos e até mesmo errôneos.

${ }^{4}$ As emissoras chamam de "janelas" os interregnos da programação em fluxo nos quais o fluxo "natural" pode ser interceptado e atravessado por imagens "estranhas" ao fluxo que interessa ao espectador. Quase sempre elas dizem respeito aos chamados espaços/tempos publicitários, mas não só.

${ }^{5}$ As diferenças serão explicitadas mais adiante.
} 
Ainda que na TV aberta e na TV por assinatura grande parte dos conteúdos assistidos advenha de "arquivos" (imagens gravadas para serem utilizadas no momento de montá-las no fluxo a que o espectador assiste), off-line produz-se um efeito de continuidade que até hoje não se conseguiu produzir on-line. Ou seja, no off-line prevalece o sentido de fluxo, como se tudo estivesse ao vivo, e no on-line prevalece o sentido de arquivo, como se sempre se tivesse que acionar algo para lhe dar vida ou movimento.

\section{Os sentidos identitários de TV off-line}

O cotejamento entre os sentidos identitários de TV off-line e TV on-line que está sendo feito nesse artigo tem por pressuposto que na TV aberta off-line - o paradigma durante do que seja a mídia TV - há algumas molduras muito sólidas que foram sendo inventadas e habituadas ao espectador na história da televisão brasileira.

Kilpp (2003), por exemplo, propôs as seguintes:

a) Emissoras televisivas e canais de televisão

Segundo a autora, no Brasil canais são lugares de fala das emissoras autorizadas pelo poder público a usá-los para transmitir seus conteúdos naquele dial. Assim, eles são territórios virtuais, visivelmente ocupados por emissoras que representam parcerias historicamente contingenciadas, territórios que se atualizam na comunicação das ethicidades ${ }^{6}$ dos brasileiros autorizados a falar sobre a brasilidade em determinados canais e nos termos dessa molduração.

A ethicidade das emissoras concessionárias dos canais, no entanto, sempre foi e é ainda enunciada pelas próprias emissoras nos modos como elas produzem e veiculam os promos relacionados a isso, e nunca elas enunciaram outra coisa que não fosse sua autonomia e independência quanto a qualquer ingerência pública sobre o que veiculam.

b) Gênero dos programas

A TV moldura o gênero dos programas que veicula de tal forma que, ao final, dá origem a um gênero televisivo e, mais do que problematizar as noções de "documental" e "ficcional", o gênero televisivo participa da dissolução de certos mundos e da instauração de outros.

\footnotetext{
${ }^{6}$ Segundo a autora (KILPP, 2003), ethicidades são construtos midiáticos daquilo que aparentemente elas, as mídias, veiculam, e cujos sentidos identitários são ofertados ao espectador-usuário a partir de um compósito de molduras e moldurações praticados habitualmente pela mídia nos modos técnicos e estéticos que são concernentes às suas lógicas operacionais, ou seja, grosso modo, concernentes à sua técnica ou ao seu algoritmo.
} 


\section{c) Programação}

A programação televisiva é uma multiplicidade de múltiplos. O termo designa desde a grade matricial matriz (na qual se imagina/projeta qual o tipo/gênero de programa que deve ir ao ar em qual horário de qual dia da semana etc.), passando pela definição do conteúdo desses ou daqueles programas por certo período de tempo (qual novela, qual programa de entretenimento, qual programa de entrevistas etc.), à programação em fluxo, a que efetivamente vai ao ar em certo período de tempocalendário (dias, semanas, meses, anos) das transmissões da emissora. No fluxo assistido, os programas são atravessados por vídeos de outras unidades autônomas que serão referidas adiante.

Ou seja, o que se chama de programação define tanto o teor principal para o espectador (o conteúdo dos programas a que ele deseja assistir) quanto o teor principal para a emissora (o conteúdo que produz maior audiência na faixa de público visado comercialmente). Nem sempre o principal de um é o principal do outro, e por isso ela é uma ethicidade/moldura contraditória, tensa ${ }^{7}$.

É a moldura das molduras - a mais televisiva de todas - aquela que as emissoras mais resistem em alterar, porquanto ela está no epicentro do "negócio televisão": ela é a paramétrica da relação ótima desejada entre a audiência e a venda dos espaços publicitários, os dois vetores que viabilizam o negócio.

Ela é, por isso, o algoritmo básico da $\mathrm{TV}^{8}$, aquele cujo funcionamento é o que mais interessa investigar em outras mídias.

d) Programas e outras unidades televisivas autônomas

Os programas e as outras unidades autônomas (os promos, as vinhetas e os anúncios publicitários, por exemplo) são alternados na sequência montada para a exibição em fluxo da programação. Mantêm-se, assim, apartados, mas ingerem-se uns sobre os outros; e decorrem dessa prática algumas questões éthicas (relacionadas aos sentidos identitários), que são também atravessadas pelas molduras e moldurações praticadas pelos programas.

É importante perceber as tensões que existem entre as molduras programa e programação, e a intervenção do “ibope" (audiência) tanto na programação quanto no programa. Isso vale também para a pesquisa, uma vez que a tendência do senso comum é avaliar e criticar a programação das emissoras pelo conteúdo dos

\footnotetext{
${ }^{7}$ Nos termos de Benjamin (2006), poderíamos dizer que é a melhor imagem dialética da TV.

${ }^{8}$ É nesse sentido que se justifica ter-se introduzido o artigo com a explicitação do que seja um programa (software) do aparelho (hardware) nos termos de Flusser (2007), porquanto, no fundo, é ele que ilumina a tese que o artigo defende.
} 
programas que foram/são/serão veiculados no período instado pelo avaliador, seja ele o espectador, o pesquisador ou o crítico. Ou seja, no mais das vezes desconsideram-se tanto a ambiência mais geral contingente (o que está acontecendo no mundo naquele momento) quanto a ambiência mais específica e fundante da mídia e de suas lógicas operacionais (o que está acontecendo na TV/emissora naquele momento). Desconsidera-se, portanto, a tecnocultura que esteve/está/estará contingenciando os conteúdos dos programas (bem como os das demais unidades autônomas e mesmo os da programação em fluxo).

A análise das partes isoladamente é incapaz de dar conta do ser televisivo. As partes em si mesmas podem ser analisadas igualmente como tais em qualquer mídia, e a avaliação e a crítica de seu conteúdo podem ser feitas independentemente da mídia e sob qualquer viés, podendo ser apenas um deles o viés da mídia TV. Portanto, contrariando práticas habituadas da pesquisa de TV, o artigo insiste em que os programas de TV não são a sua essência, e que a moldura das molduras de TV é a programação, nos termos referidos anteriormente.

e) Panoramas televisivos e moldurações intrínsecas

As moldurações intrínsecas dos panoramas televisivos são indicativas de muitas e diversas práticas de montagem que têm implicações no sentido atribuído ao conteúdo veiculado nos panoramas, no écran do monitor. Nos termos do cinema, pensaríamos na composição interna dos quadros e planos. Entretanto, na TV elas precisam ser entendidas ainda sob a lógica da programação em fluxo, porquanto são atravessadas pelas demais molduras e moldurações aí sobrepostas.

f) Televisão

A televisão a que se assiste na TV aberta off-line é também, ela mesma, um construto televisivo, na medida em que ela diz o tempo todo como pretende ser entendida em certos momentos de certas tevês: como produtora de mercadorias culturais; como vitrine de mercadorias produzidas pela indústria (cultural ou em geral); como plantão do "acontecimento" histórico; como memória do já acontecido etc.

\section{Os sentidos identitários de TV na Internet}

Por conta dos avanços da digitalização e da expansão dos usos da Internet para usuários também em expansão, nos últimos anos vem crescendo aceleradamente a oferta de conteúdos televisivos on-line. Isso ocorre em diversos sítios da rede mundial de computadores sob uma multiplicidade de formas, de acordo com uma também crescente diversificação e ampliação dos interesses, sejam estes dos sítios, da rede ou dos usuários. Aqui importa destacar os relacionados à TV. 
Verifica-se que os conteúdos de programas televisivos têm se espraiado na rede, e eles são, sem dúvida, o mais forte comparecimento da TV no conjunto dos sítios monitorados. Mas não só eles: também a estética dos panoramas e das moldurações intrínsecas; as lógicas operacionais ambivalentes e imprecisas do que sejam "emissoras" e "canais"; a molduração confusa do gênero dos "programas", do “ao vivo" (streaming) e do "pré-gravado" (arquivo) etc. É compreensível, portanto, que o fenômeno venha criando inúmeros desafios à pesquisa, que às vezes insiste em olhar para a história/progressão das mídias pelo espelho retrovisor de um carro em movimento 9 e, assim, generaliza-se o entendimento de que tudo isso ainda é TV.

É verdade que em tudo isso ainda há muito de televisão; ou que há muitos traços ou vestígios da TV off-line que duram ou perduram (ou, como preferem alguns ${ }^{10}$, remediam-se) na nova mídia. Mas não se pode ignorar que talvez a ethicidade da TV na Internet seja outra coisa, um construto da nova mídia de algo que ainda não tem nome próprio. TV on-line? Web TV? TV expandida?

Já que - como se está propondo - o conteúdo dos programas não é o que define a essência da TV, a questão que se coloca, então, é: o que dura (ou perdura) na mídia Internet da mídia televisão que conhecemos?

O paradigma que se adota para problematizar o praticado off-line e on-line com vistas a responder à questão é a moldura que Kilpp (2003) considerou ser o algoritmo da TV: a programação. Os objetivos principais deste artigo, portanto, passam a ser:

a) autenticar as práticas enunciativas da ethicidade TV na Internet;

b) cartografar as moldurações praticadas na Internet para conferir sentidos identitários de programação (televisiva) aos conteúdos nela veiculados, em sítios que se dizem relacionados à TV, especialmente nos das emissoras off-line e nos das chamadas webTVs ${ }^{11}$.

Embora haja diferenças nas moldurações praticadas pelo conjunto dos sítios monitorados na pesquisa, escolheram-se dois para comentar nesse artigo, um de uma TV off-line (a TV Bandeirantes) e um de uma webTV (a Ustream.TV). O

\footnotetext{
${ }^{9}$ Imagem proposta por McLuhan (1999), que será comentada mais adiante.

${ }^{10}$ A partir de Bolter e Grusin (1999).

${ }^{11}$ Embora a pesquisa relatada inclua fazer as mesmas considerações/ponderações/problematizações quando se trata da veiculação dos mesmos conteúdos em dispositivos móveis (sob os quais há ainda o atravessamento de outras molduras e moldurações), eles não serão considerados aqui. Aqui, trata-se apenas dos observáveis em telas de monitores de TV e computadores domiciliados, o que é uma das etapas da pesquisa.
} 
critério para a escolha foi que os dois sítios oferecem melhores imagens médias ${ }^{12}$ para a análise do fenômeno pautado.

\section{Molduras de programação na TV Bandeirantes on-line}

Para monitorar a atuação da TV Bandeirantes em aparelhos de TV e em computadores domiciliados, selecionou-se um programa qualquer da grade de programação semanal da emissora que era veiculado "ao vivo", ou seja, que a princípio inscreveria o programa na programação em fluxo mantendo a lógica off-line de o programa ser moldurado pela programação. Optou-se por esse procedimento porque "programação" na Internet é outra coisa do que "programação" off-line e, no mais das vezes, é uma coleção (arquivo) de programas (vídeos) ${ }^{13}$. Sua organização (e acesso) se faz por gênero e/ou categoria, que também não são, muitas vezes, os praticados off-line. Apenas no "ao vivo" o acesso e a espectação podem se dar à semelhança dos da programação off-line (que é organizada por horário e sequencialidade), em fluxo.

Mas, antes, para entender como a Band TV se diz TV na Internet, iniciou-se por sua busca na rede. O buscador escolhido foi o Google, que devolveu cerca de 287.000.000 resultados (em 0,20 segundos) ${ }^{14}$, um número bastante expressivo, admita-se, ainda que de fato os que interessam aqui sejam muitíssimo menos. Isso ocorre porque a mídia Internet produz associações ao termo da busca feita pelo usuário conforme seu algoritmo, programado para estabelecer todas as associações imagináveis ao termo no vasto universo de dados on-line, que segue expandindo-se ao infinito. Não há de ser à toa, portanto, que se pense às vezes a rede mundial de computadores como a realização em curso da sonhada biblioteca universal, na qual estariam reunidos todos os dados alguma vez produzidos e arquivados por

\footnotetext{
${ }^{12}$ Quando diante de imagens em movimento, como as produzidas pelo cinema, não há diferenças significativas entre umas e outras montadas em sequência, Bergson (2005) propôs o termo-conceito “imagem média” para designar aquela que sintetizaria as imagens da sequência. Também se refere a quando, diante de interfaces gráficas que vão sendo movimentadas durante a navegação em um sitio qualquer, encontram-se imagens médias das interfaces de cada sitio. Também no fluxo televisivo há imagens médias das montagens praticadas por um programa e por outro, por uma emissora e por outra na interface gráfica. Por exemplo, no caso da TV off-line, são recorrentes e generalizadas as inscrições, pelo menos, das logomarcas da emissora e do programa, e essa é ima imagem média dos panoramas de todas e quaisquer emissoras; o que muda de uma imagem para outra é o design dos logos e sua posição no écran.

${ }^{13}$ Esse é um dos sintomas do estado-vídeo dos audiovisuais na Internet que se pretende salientar no artigo: qualquer audiovisual off-line, de TV ou de cinema, acaba, na Internet, em uma plataforma de vídeos, como, aliás, bem define o YouTube, a Globo Vídeo, as emissoras analisadas no artigo (principalmente a Ustream.TV) etc.

${ }^{14}$ Acesso em: 9 out. 2016.
} 
alguém: toda a memória do conhecimento produzido pela humanidade ${ }^{15}$. Jamais algo parecido se realizará off-line, mesmo que sonhado por cientistas há cerca de dois mil anos. Sonho, utopia ou possibilidade, entretanto, é o horizonte para o qual mira a rede de computadores, especialmente nos algoritmos dos inúmeros sistemas de busca e associações, que têm a ver com isso antes de tudo e muito menos com os interesses do usuário. E chega a ser constrangedor comparar tal horizonte com o relativamente medíocre horizonte da programação das emissoras de TV, não obstante tenha sido a primeira mídia a alcançar uma expressiva globalização, e ainda que venham sendo construídos inestimáveis bancos de dados memoriais da humanidade televisualizada.

Dentre os nove resultados que apareceram na primeira página ${ }^{16}$, os primeiros apontavam para o sítio on-line da emissora. Ao clicar no primeiro resultado, chegou-se à seguinte URL: <www.band.uol.com.br/tv>, a primeira aparição do conteúdo do site moldurado como produto de algo chamado de TV.

Nessa página, duas molduras indicavam "Programação - No ar" e "ver programação completa”. Nas duas alternativas de navegação/assistência oferecidas, abaixo do título programação apareciam imagens síntese ${ }^{17}$ dos programas ali enquadrados, sob as quais havia o título do programa e um texto bastante curto e explicativo de seu teor (supostamente produzido para veiculação na Internet, aos seus moldes). Havia também, ao lado direito da interface, na mesma linha horizontal das duas molduras citadas, uma terceira moldura, graficamente diferenciada, intitulada "MODATOI", sob a qual se anunciava, com descontos de 50 e 66\%, modelos de tênis para "compre", dois em cada coluna de oferta.

Foram esses os primeiros ruídos observados, alertando para o fato de se estar numa mídia em que as molduras e moldurações de programa e programação diferem das praticadas pela TV off-line.

\footnotetext{
${ }^{15} \mathrm{O}$ artigo de Fidalgo $(1997$, p. 1) consubstancia bem essa idéia. Por exemplo, diz ele na primeira página: "A compilação do saber, de todos os conhecimentos em todas as áreas, obtidos em todas as épocas, em todos os lugares, foi sempre uma aspiração, ou pelo menos uma tendência, de todas as comunidades científicas. [...] Graças à digitalização e às telecomunicações, podemos vislumbrar a realização do sonho de uma biblioteca universal. [...] Ora, se atendermos bem às possibilidades da rede de computadores, veremos que as funções de recolha, consulta, leitura, e até de esconder, podem ser cabalmente realizadas na biblioteca virtual”.

${ }^{16}$ Os primeiros resultados que aparecem na primeira página de resultados de qualquer busca têm sido cada vez mais os relacionados à publicidade de coisas afins aos termos da busca. Depois, abaixo, aparecem aqueles dos quais se está falando aqui.

${ }^{17}$ Essas imagens podiam ser uma imagem média, mas quase sempre eram imagens conceituais publicitárias, como o frame de uma chamada de programa ou a imagem de um cartaz de filme.
} 
Abrir parênteses. Antes de se chegar a esse sítio, passa-se por interfaces ou telas nas quais há outros ruídos operacional-enunciativos mais genéricos e óbvios. Por exemplo, não é suficiente ligar o aparelho e sintonizar o canal (a lógica prevalente no acesso a conteúdos televisivos off-line). Ou seja, é necessário ligar o computador, acessar a Internet, buscar o sítio on-line da emissora e, nele, acessar ou a "Programação - No ar" ou "ver programação completa” e, só então, chegar, navegando (quer dizer, tendo sempre de fazer escolhas e clicar em molduras-link ofertadas ao usuário para prosseguir a navegação). No percurso, passa-se ainda por vários outros elementos estranhos, no mais das vezes relacionados a práticas que vêm sendo ensaiadas na Internet para financiar a veiculação de conteúdos por empresas patrocinadoras, que têm, também, de inventar formatos e estratégias publicitárias quase sempre inexistentes off-line. Fechar parênteses.

Ao clicar na moldura-link de programa que estava no ar, era-se direcionado para a página do programa dentro do site da emissora. Para assistir ao conteúdo, bastava dar play na tela que ela trazia ao vivo a transmissão daquele programa. Assim, foi possível acompanhar a transmissão do programa ao vivo na televisão domiciliada e na Internet, e verificou-se que tudo que passava na televisão off-line também passava on-line, simultaneamente, inclusive os comerciais. Ou seja, após alcançar a transmissão (passando por várias molduras existentes apenas on-line), encontrava-se de fato o mesmo conteúdo televisivo.

\section{Molduras de programação na Ustream.TV}

A Ustream pode ser uma webTV, originária da Internet, e como tal é um construto (uma ethicidade) da nova mídia, exclusivamente. Também pode ser uma plataforma de vídeos on-line e de transmissões ao vivo, como será argumentado mais adiante. Entretanto, enuncia-se primeiramente TV e depois plataforma de vídeos (e streaming - "stream" que, aliás, também participa do nome do site). Por quê?

Ela foi localizada no endereço <http://www.ustream.tv> seguindo a mesma lógica utilizada para buscar no Google emissoras de TVs off-line sob os termos TV, TV on-line e webTV. Dentre os resultados obtidos, três correspondiam integralmente ao critério webTV, sendo que a Ustream se apresentou como aquela que oferecia as melhores imagens médias para análise da moldura programação na circunstância de seu habitat ${ }^{18}$.

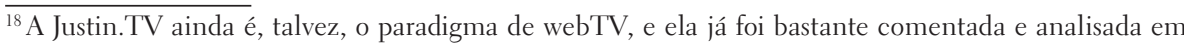
outros textos. No entanto, as melhores imagens médias para fins da análise em pauta não são as suas, mas as da Ustream.TV, um site que se parece mais com a média dos sites em que a problemática TV on-line se enuncia sob a moldura programação, que é o algoritmo da TV off-line, como já se disse.
} 
Embora o termo "TV" esteja pontuado na URL do site ${ }^{19}$ (grifado em vermelho na captura de tela abaixo, Figura 1), no teor da página inicial não se encontrou referência alguma ao termo; em contrapartida, apareceram duas referências ao termo "vídeo" (grifado em vermelho pelo autor na mesma imagem): na moldura-identidade da marca Ustream ("THE FUTURE OF VIDEO"), em caixa alta e centralizada ${ }^{20}$ na página; e no comentário explicativo abaixo da imagem centralizada ("Online video and live streaming platform"). O termo aparece mais duas vezes abaixo, em "Broadcast to anyone" e em "Stream E share securely".

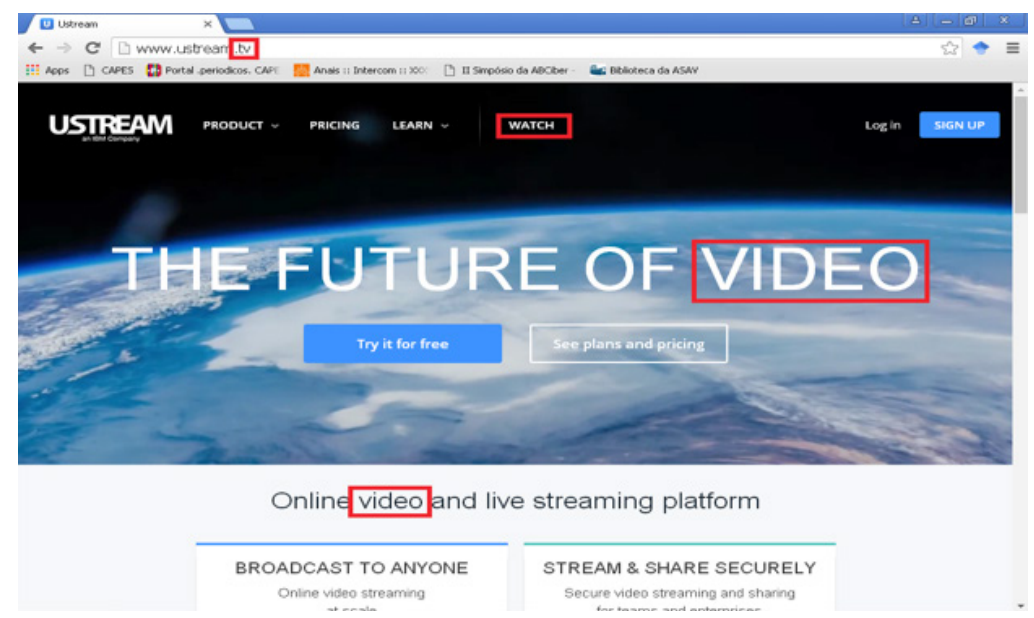

Figura 1: Captura de tela da página inicial da Ustream.TV.

Fonte: <http://www.ustream.tv>. Acesso em: 15 ago. 2016.

As cinco molduras (uma de TV e quatro de vídeo) tinham espaço privilegiado na interface gráfica da página inicial do site, o que atesta sua importância para os administradores do canal. Mas que sentido pretendiam que se atribuísse a um termo e ao outro?

Ao clicar na moldura-link "Watch" no menu principal, à direita do logo do canal, chegava-se a uma página (Figura 2) que dava um preview do que parecem ser imagens síntese ou médias das empresas associadas ao canal, sendo que este se apresenta, junto a seu logo, em letras minúsculas, como an IBM company (por extenso, seria USTREAM,

\footnotetext{
${ }^{19}$ Acesso em 15 ago. 2016.

${ }^{20}$ A centralidade de uma informação no quadro como forma de destacar o tema, objeto ou sentido da imagem remonta à perspectiva renascentista, a qual continua sendo praticada até hoje pela fotografia, pelo cinema, pela televisão etc. como enquadramento clássico do principal.
} 
an IBM company). Ora, o que faz a IBM nesse universo on-line de TVs e vídeos? E de streaming? À primeira vista, se a Ustream hospeda customers relacionados aos seus interesses estratégicos, estes são parte dos interesses da IBM: desenvolver e expandir para todo o mundo as tecnologias de informação que são seu negócio principal ${ }^{21}$, frisando que a Ustream é uma companhia da IBM, conforme declarado na página!

Sob a moldura-título "Featured customers", aparecem duas linhas, cada uma com quatro imagens síntese dos conteúdos veiculados pelos customers. A única das oito imagens mostradas que se relacionava a TV era a da NASA TV (da National Aeronautics and Space Administration), que tinha como moldura complementar a explicação "Live now".

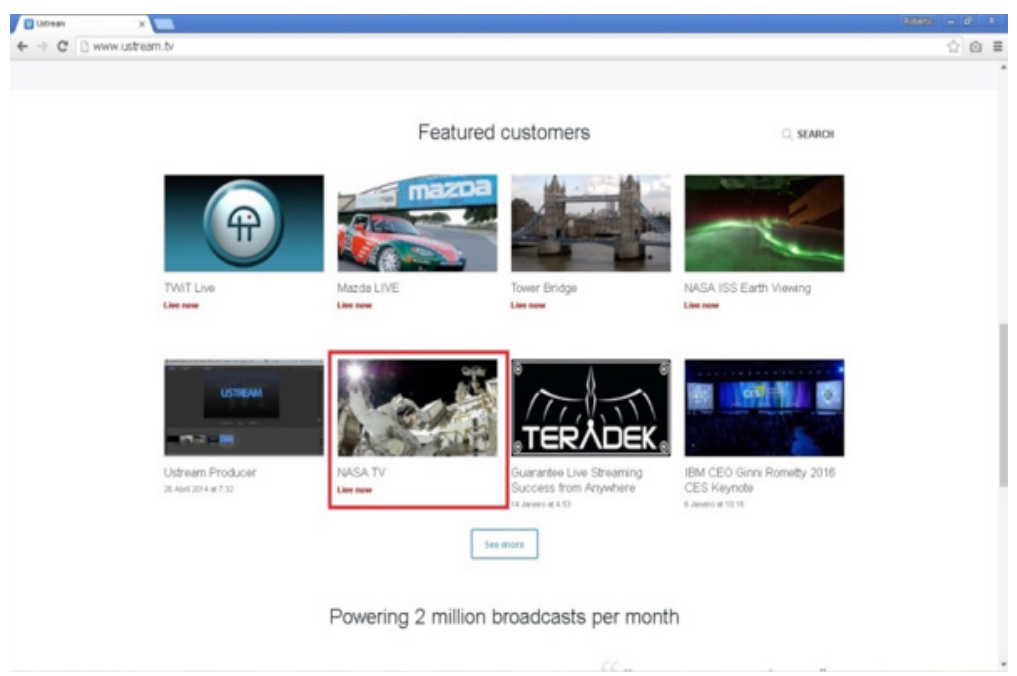

Figura 2: Captura de tela da página "Featured custormers" da Ustream.TV.

Fonte: <http://www.ustream.tv>. Acesso em 15 ago. 2016.

Ao clicar na imagem moldura-link era-se remetido à página de streaming da até então (na navegação) designada NASA TV (Figura 3). Ou seja, sem clicar em nada mais, assistia-se ao conteúdo da programação em fluxo da emissora (de TV, por definição), como ela se desenrola habitualmente e como se a assiste em qualquer

\footnotetext{
${ }^{21}$ Segundo a Wikipedia (IBM, 201-?), "International Business Machines (IBM) é uma empresa dos Estados Unidos voltada para a área de informática. A empresa é uma das poucas da área de Tecnologia da Informação (TI) com uma história contínua que remonta ao século XIX. A IBM fabrica e vende Hardware e Software, oferece serviços de infraestrutura, serviços de hospedagem e serviços de consultoria nas áreas que vão desde computadores de grande porte até a nanotecnologia.".
} 
emissora de TV off-line: intercepta-se o fluxo em algum momento de seu desenrolar e se segue (ou não) a narrativa em curso.

Entretanto, nessa página a emissora já não mais se intitulava TV, mas "NASA Public-Education" (algo como "NASA Educação Pública"). O logo, ainda visível, seguia sendo NASA TV, mais a explicação Public-Education abaixo, e o conteúdo rolava em uma moldura-tela assemelhada à de um monitor de TV, inclusive com a indicação de "LIVE" no canto superior direito.

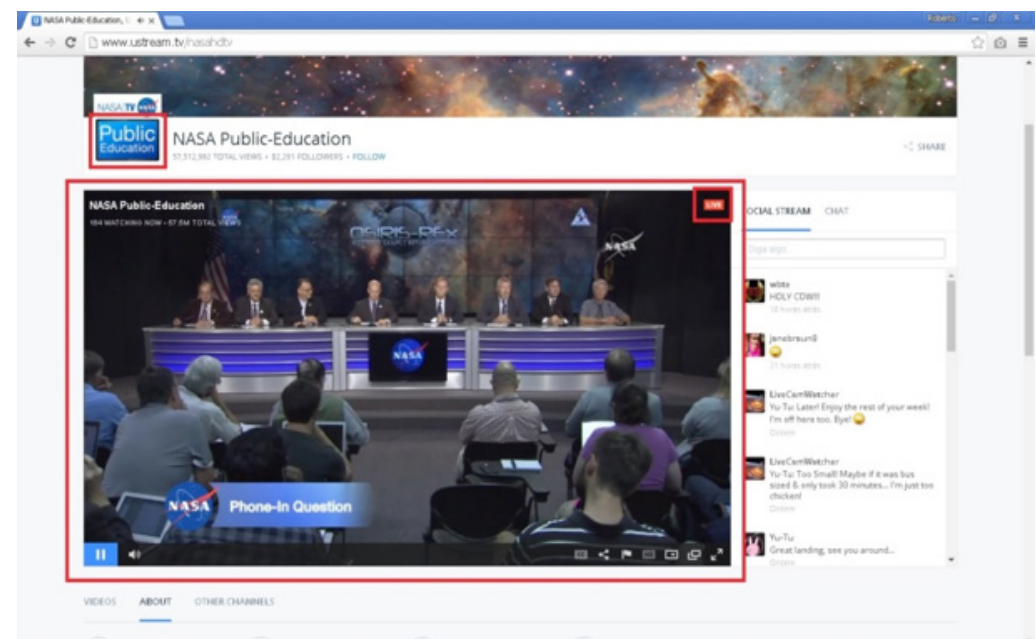

Figura 3: Captura de tela da página NASA TV da Ustream.TV. Fonte: <http://www.ustream.tv>. Acesso em 15 ago. 2016.

Ou seja, os conteúdos televisivos ocasionalmente veiculados no site se prestam a interesses que só têm a ver com a mídia TV muito indiretamente, como um dos resultados (produtos) esperados do desenvolvimento das tecnologias da informação para a comunicação - uma das leituras possíveis da consagrada sigla TICs (tecnologias da informação e comunicação) -, desenvolvimento esse que se apropria de formatos e linguagens televisivos para fins, por exemplo, didáticos.

\section{Considerações finais}

Investigar a televisão durante na Internet justifica-se por conta da persistência da TV off-line como paradigma para interpretar os conteúdos televisivos ali assistidos. Décadas atrás McLuhan (1999) denunciou que o que fazíamos para entender a televisão era olhar através de um espelho retrovisor, e que tentávamos enxergar na então nova mídia aquelas que a precederam, especialmente o cinema. Parece que o feitiço se virou 
contra o feiticeiro: hoje, ninguém mais, em sã consciência, procura cinema na TV; mas muitos ainda procuram TV onde ela talvez não esteja. McLuhan (1999) também disse, então, que a velha mídia era o conteúdo da nova, e que a mensagem do meio não estava nesse conteúdo, mas no meio ele mesmo, entendimento que foi reiterado pelo autor na célebre frase “o meio é a mensagem”, parafraseada (também por ele próprio) no título de uma de suas mais controversas e criticadas obras, escrita em parceria com o designer Quentin Fiore: O meio são as massagens (1969)22.

$\mathrm{O}$ autor talvez se preocupasse hoje com a frequente primazia do conteúdo televisivo na análise de mídias tão outras, nas quais assistimos a tais conteúdos. Preocupa mais, porém, a primazia daquele viés que aponta para o declínio de sua audiência causado pela Internet (leia-se redes sociais e YouTube, principalmente) ${ }^{23}$. Paradoxalmente, esse viés tem por referência justamente os conteúdos televisivos veiculados nesses sítios e, desde tal perspectiva, seria mais correto dizer que, ao contrário, a Internet aumentou a audiência dos conteúdos televisivos, porque os disponibilizou a segmentos de espectadores menos afins à assistência domiciliada (e familiar) da televisão off-line. Ou seja, na medida em que os conteúdos passaram a poder ser assistidos mais individualmente, ao jeito, local e horário de cada um, eles ganharam o interesse de novos públicos em diferentes telas. Essa ponderação sugere que se volte a considerar a ingerência do "estado televisão" sobre os sentidos, o que já foi mais praticado pela pesquisa num estágio anterior da técnica.

Estado televisão é um conceito relacionado à "ambiência” na qual emissor e receptor se encontram com os conteúdos televisivos veiculados numa e noutra mídia. Considerar seu protagonismo nos agenciamentos de sentido implica levar em conta as condições físicas, tecnológicas, materiais e imateriais etc. de recepção de programas de televisão em aparelhos domiciliados, porquanto ambiências, na perspectiva de Kilpp (2003) são molduras "primeiras”, tecnoculturais ou socioambientais em sentido

\footnotetext{
${ }^{22}$ Há nesse título, assim traduzido para o português, uma riqueza semântica bastante ilustrativa do que o autor entendia sobre o meio ser a mensagem. Lembremos que o autor se referia à polêmica mídia emergente chamada televisão. Há os que leram "massagem" como um desdém e uma (des)qualificação da TV: ela massagearia as massas com vistas à sua alienação política. Essa leitura foi defendida, a favor e contra o autor, no sentido de que haveria um bem ou um mal na técnica em si mesma e em sua progressão, e é uma perspectiva antes de tudo ideológica acerca da industrialização ou massificação da cultura. Uma outra leitura possível, genealógica, a qual se defende aqui, é que, entre a formulação original em inglês e a formulada em português, haja um interregno nos termos "mass" e "gen", o que nos poderia levar a entender a TV como o gene do massivo, porquanto, de fato, a TV foi a primeira grande mídia de massas. O fenômeno não começa com ela, mas ela representa muito bem esse gene da comunicação: ela pode ser pensada como uma imagem média do fenômeno, em curso desde o início histórico da chamada industrialização da cultura, a qual, entretanto, também já existe como devir desde o surgimento da comunicação.

${ }^{23}$ É um viés mais jornalístico ou mercadológico do que epistemológico.
} 
largo; são parentes próximos dos frames antropológicos de Goffman (1974); e com certeza é um conceito que dialoga com a dialética entre a figura e o fundo proposta por McLuhan e McLuhan (1990). Às vezes elas foram ignoradas pela pesquisa, mas poucas vezes elas foram ignoradas pelos criadores de conteúdos televisivos, que os produzem imaginando a quem eles são direcionados e sob quais condições eles serão assistidos e que, por isso, levam em conta tanto o ambiente sócio-técnico de recepção quanto o repertório estético-cultural presumido do espectador ideal ${ }^{24}$.

Portanto, há ainda uma outra moldura "primeira”, talvez até mais importante e decisiva, dependendo da episteme com a qual se esteja operando: a moldura "corpo" do espectador. Bergson (1999), por exemplo, propõe que o universo é um conjunto de imagens cujo epicentro é a imagem de nosso próprio corpo, a única que é possível conhecer também de dentro. Segundo o autor, nosso corpo percebe as imagens de outros corpos conforme sua necessidade pessoal de agir (leia-se sobreviver ou durar); embora todas as imagens sejam registradas na memória pura, apenas uma parte delas - as que nos são úteis no presente - são acionadas para agir aqui e agora -, e é a partir de tais imagens-lembrança que percebemos as demais imagens. Hansen (2004), na esteira de Bergson, propõe o conceito embodiment (corporificação, pessoalização) para explicar a centralidade do corpo na percepção, criação e ação dos sujeitos na contemporaneidade, na arte e na comunicação. Didi-Huberman (1998), na esteira de Benjamin, seculariza os conceitos de aura e imagem dialética para explicar a duração do passado em imagens do presente que, ao ser assim autenticado pelo pesquisador, autoriza que se admita haver uma imagem (imaginada ou autenticada pelo pesquisador) que critica a imagem presente (materializada em algum suporte), porquanto, de fato, esta é assombrada por imagens-lembrança que deixam nela rastros do passado memorial.

É assim desde antes das imagens técnicas e/ou das mídias (como se as hoje entende). É uma perspectiva complexa que vale, por exemplo, para a análise dos sentidos das pinturas rupestres e das pinturas e esculturas em igrejas medievais; vale também para a análise dos sentidos das imagens feitas a partir da Renascença para serem exibidas em museus e galerias; e vale para a análise dos sentidos das imagens do Instagram ou do YouTube quando se as produz, assiste (e usa) no computador ou no celular, por exemplo. É uma perspectiva útil e talvez necessária até para analisar os sentidos das imagens da caverna de Platão.

\footnotetext{
${ }^{24}$ Depois da literatura, a TV foi a mídia que mais levou em consideração um presumido leitor/espectador ideal quando criou a grade de programação matricial, décadas atrás.
} 
Mas, se é fácil perceber a ingerência dessas molduras primeiras (a ambiência e o corpo/memória do espectador) quando se está comparando imagens distantes umas das outras no tempo histórico e no espaço físico e cultural em que foram produzidas e veiculadas, é (muito mais) difícil quando se comparam imagens contemporâneas de mídias contemporâneas, como é o caso aqui.

Reforça-se, assim, a necessidade de se conjeturar, por exemplo, sobre a produtividade de uma epistemologia clássica do cinema (expandida para o audiovisual lato sensu), da montagem técnica na significação dos conteúdos televisivos em si mesmos - autônomos e independentes - porquanto, ainda que seja decisiva, a montagem ${ }^{25}$ per se não diz/explica tudo. Muitos montadores entenderam isso e passaram a incluir em sua prática a consideração das condições de recepção e, hipoteticamente, a subjetividade do espectador $a, b$ ou $c$. Mas, também, muitos montadores não se deram conta disso, ou o ignoraram.

No monitoramento das moldurações praticadas na Internet para ofertar sentidos identitários de TV aos conteúdos televisivos assim declarados nos sítios escolhidos para a análise, percebeu-se haver muito mais fortuidade (acontecimento!) do que boa parte de nossas pesquisas consegue apreender para explicar o sucesso ou o fracasso de um empreendimento qualquer quando se trata da digitalização de conteúdos quaisquer em sítios quaisquer da Internet.

Ainda que se tenha insistido, a partir de Kilpp (2003), no algoritmo de TV como estando intimamente relacionado à moldura programação, é preciso reconhecer que essa sólida e decisiva moldura não é suficiente para concluir se os conteúdos televisivos sob o formato grade de programação ou de programação em fluxo veiculados nos sítios da Internet analisados se relacionam de fato à duração (atualizada) da mídia TV na Internet ${ }^{26}$.

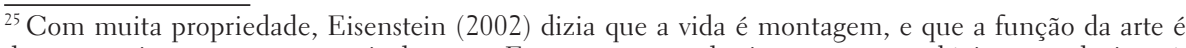
dar a ver tais montagens a partir das suas. E que o sucesso das invenções tecnológicas se relaciona à capacidade da ciência de montar a vida de outro jeito para que, como extensões humanas, os artefatos (ou meios) que inventamos sejam efetivos na resolução de nossos problemas como espécie. Somos uma espécie insuficientemente preparada biologicamente para o embate que travamos diariamente com a natureza (com vistas a melhor conhecê-la e a controlá-la a favor de nossa subsistência como espécie). Por outra via e por outras razões, segundo Benjamin (2012), há muito se vem criando uma segunda natureza (a tecnológica), a qual, entretanto, demanda outras abordagens para que seja mais bem entendida e controlada a favor de nossa subsistência.

${ }^{26}$ Como já se disse antes, a programação em fluxo dos conteúdos televisivos nos sites analisados só era bastante afim à programação em fluxo das TVs off-line quando se tratava de transmissões ao vivo ou em streaming, excetuando-se a montagem, nos fluxos, das unidades autônomas. Até o momento do monitoramento feito, apenas nas transmissões off-line todas elas eram partes da macroprogramação (a programação em fluxo). Na Internet, a tendência era manter as unidades não relacionadas ao conteúdo dos programas apartadas do fluxo.
} 
Alternativamente, então, conjetura-se haver um outro estado, no qual nos situamos em trânsito, e que é transversal e ubíquo: o estado-vídeo. Assim proposto por Dubois (2004, p. 111), o "estado-vídeo é uma forma que pensa [...] O vídeo é, na verdade, essa maneira de pensar a imagem e o dispositivo, tudo em um. Qualquer imagem e qualquer dispositivo". Ou seja, Dubois não pensa o vídeo como certo audiovisual de certa mídia, e sim como uma forma que pensa sobre quaisquer vídeos de quaisquer dispositivos.

A partir do que se autenticou no monitoramento efetivado, e considerando todas as referências teóricas apontadas no artigo, conclui-se que, talvez, mais do que problematizar a duração televisiva na Internet seja inevitável refletir sobre o que essa forma que pensa o audiovisual como estado da tecnocultura (estágio da técnica, estágio das relações entre produção e consumo etc.) tem a nos dizer sobre a televisão. E sobre outros meios audiovisuais. E sobre a experiência do mundo que é regulada pelas lógicas do estado-vídeo. E, finalmente, sobre os vídeos assistidos, nesse estado, em que os conteúdos ditos televisivos veiculados podem não ter sequer a ver com os conteúdos televisivos da mídia TV, porque se situam em outros campos do saber.

\section{Referências}

BENJAMIN, W. Passagens. Belo Horizonte: Ed. da UFMG, 2006.

A obra de arte na época de sua reprodutibilidade técnica. Porto Alegre: Zouk, 2012.

BERGSON, H. Matéria e memória. São Paulo: Martins Fontes, 1999.

. A evolução criadora. São Paulo: Martins Fontes, 2005.

BOLTER, J. D.; GRUSIN, R. Remediation. Cambridge: The MIT Press, 1999.

DIDI-HUBERMAN, G. O que vemos, o que nos olha. Rio de Janeiro: Editora 34, 1998.

DUBOIS, P. Cinema, vídeo, Godard. São Paulo: Cosac Naify, 2004.

EISENSTEIN, S. A forma do filme. Rio de Janeiro: Zahar, 2002.

FIDALGO, A. A biblioteca universal na sociedade de informação. 1997. Disponível em: <https://bit.ly/2s2obSw>. Acesso em: 25 dez. 2016.

FLUSSER, V. O mundo codificado. São Paulo: Cosac Naify, 2007. 
GOFFMAN, E. Frame analysis: an essay on the organization of experience. Nova York: Harper \& Row, 1974.

HANSEN, M. New philosophy for new media. London: MIT Press, 2004.

IBM. In: WIKIPÉDIA: a enciclopédia livre. San Francisco; Los Angeles: Wikimedia, [201-?]. Disponível em: <https://bit.ly/2s1BX8J>. Acesso em: 30 dez. 2016.

KILPP, S. Ethicidades televisivas. São Leopoldo: Ed. da Unisinos, 2003.

MCLUHAN, M. Os meios de comunicação como extensões do homem. São Paulo: Cultrix, 1999.

MCLUHAN, M.; FIORE, Q. O meio são as massagens: um inventário dos efeitos. 2. ed. Rio de Janeiro: Record, 1969.

MCLUHAN, M.; MCLUHAN, E. Leyes de los medios: la nueva ciencia. Ciudad de México: Alianza; Consejo Nacional para la Cultura y las Artes, 1990.

NATIONAL AERONAUTICS AND SPACE ADMINISTRATION. Ustream: an IBM Company. [201-?]. Disponível em: <https://bit.ly/ljPMYBu>. Acesso em: 15 ago. 2016.

submetido em: 22 nov. 2017 | aprovado em: 23 abr. 2018 